\title{
Regulation of tourist dress ethics in the realization of maritime- based halal tourism in Sabang city
}

\author{
Naili Sumaiya ${ }^{1}$ and Muhammad Adli Abdullah ${ }^{2 *}$ \\ ${ }^{1}$ Research Center for Marine Sciences and Fisheries, Universitas Syiah Kuala, Banda Aceh 23111, Indonesia. \\ ${ }^{2}$ Department of Custom Law, Faculty of Law, Universitas Syiah Kuala, Banda Aceh 23111, Indonesia.
}

\begin{abstract}
The indications of halal values in the local regulation need to be looked at further on the overall coverage of halal aspects included dress ethics that need to be applied to support halal tourism with local identity and global competitiveness. The Aceh government which has special autonomy under the leadership of the mayor of Sabang, has issued special regulations to support the implementation of 'good' and 'halal' tourism. This regulation is stated in Qanun Number 9 of 2019 concerning the Master Plan for Tourism Development of Sabang City for 2019-2027. The stipulation of these regulations clearly indicates the spirit of halal, including the ethics of dress which is a local identity in the management of marine tourism in the city of Sabang which can be seen in many poins of mentioned qanun. Normative research by looking at the scope of government regulations that is presented qualitatively shows the need for the scope of rules or derivative rules from the side of non-muslim tourists in terms of the obligation to comply with local halal norms and ethics, such as etiquette for beachfront dress and supervision. This is because the embodiment of halal tourism in products, governance, facilities, and supervision must support social, ethical, customary and local communities. The preference for halal tourism that has been declared by the government must not prioritize the quantity of tourism but prioritize the quality of halal, wisdom and social culture of the local community.
\end{abstract}

\section{Introduction}

Sharia law in every field, both in the field of muamalat and in the field of worship, aims to bring people to the achievement of a falah life/happiness in the world and the hereafter. The field of muamalah is the dominant aspect of activity carried out in human life. Focused attention in this area is needed in order to create the goals of the Shari'a.

The term of Halal is the norms and rules of Muslim life that are inherent and should be maintained in every practice of life, including tourism. Aceh, which is an area that holds the norms and rules of life of Islamic law, is certainly more stressed to practice halal principles in tourism development.

Certainly, the archipelagic area is the main natural marine tourism location which has a great attraction for tourists to visit the area/city. Aceh has many natural marine tourism sites, even in the form of special islands. Although many islands in Aceh are still isolated from visits by foreign tourists, the city of Sabang has attracted their arrival because it has several islands as attractive destinations. Of course, in improving regional tourism, the Aceh government, which has special autonomy under the leadership of the mayor of Sabang, has issued special regulations to support the implementation of good and 'halal' tourism as a characteristic of Aceh. The Qanun that regulates Sabang tourism is Qanun Number 9 of 2019 concerning the Master Plan for Sabang City
Tourism Development for 2019-2027 [1]. The spirit embodied in the qanun has briefly shown the purpose of realizing halal tourism. However, the practice of tourism in the field still shows that it is not halal or contrary to local ethics which is shaded by the labeling of the area as 'veranda of Mecca'. Ethics is explained as differentiating between correct and incorrect, it is imbibed by the individual, group in society and business organization [2]. In this case, especially the practice of how to dress tourists when traveling to the city of Sabang which is very contradictory. This gap in practice shows that there is a gap in regulation or even if it is not regulated.

\subsection{Halal tourism as Islamic tourism}

Fundamentally, halal tourism and Islamic tourism are the same terminology because one is part of the other. However, on the other hand, they both have different meanings. Islamic tourism is a term commonly used in the world to refer to tourism areas that are centers of Muslim visits. Meanwhile, halal tourism is part of Islamic tourism which can cover a wider range than that, which in this case does not only include Muslim tourists but also non-Muslim tourists in maintaining halal norms. Tourism is generally defined as:

"Tourism is a complex phenomenon with sociological, behavioral, economical, political, cultural and environmental dimensions influencing every aspect

\footnotetext{
*Corresponding author: bawarith@unsyiah.ac.id
} 
of life in modern societies and scientists have difficulties in drawing its borders. Much has been achieved in tourism studies in the 1990s. A number of books and academic journals have been published in tourism, hospitality and related areas. However, it is hard to make the same conclusion for studies related to tourism and its relationship with the religion of Islam and Islamic consumption [3]. Leisure and mass tourism usually related to negative impacts to the local residents especially for social and cultural impact [4].”

Meanwhile, Islamic tourism includes activities (eg, Muslims), locations (eg, Islamic destinations), products (eg, accommodations, food and beverage), dimensions (economic-cultural-religious) and management of the service production process (eg, marketing and ethics) [3]. In Islam, the halal measure is used to indicate whether something is allowed to be consumed or used. In other words, halal terminology is used to indicate the consumption and use of something that is not prohibited by the Qur'an or Sunnah. The relationship between tourism and religion is:

"competition, mutual influence, being complimentary and co-habitual. An Islamic tourism concept also brewed with economic concept, cultural concept and religion conservative concept. However, the relationship of tourism and religion can reduce the risk of negative encounters between tourist and the host [4]."

\section{Methods}

\subsection{Types of research}

This research is in the form of literature research. The research was purposing to analyze the local regulation and the opportunity to realize the real of halal tourism. The approach used is a qualitative normative approach in the form of detailed elaboration on halal tourism and its connectivity to tourist dress ethics.

\subsection{Targets/subjects of research}

This research indicates the regional regulation on tourism as a target of research. With this, the study will focus on matters relating to how deep-covered the local rule to dress ethics.

\subsection{Data analysis technique}

Data analysis in this research based on literature review that was conducted in an inductive descriptive manner.

\section{Result and discussion}

Some of the general parameters used in measuring halal tourism are the quality of the attitude of the population in applying Islamic law, the city life system/regulation in placing Islamic law as a guide to life, and obedience to Allah [5]. The guide to the implementation of halal tourism is a complex guide that focuses on the implementation of halal tourism for Muslim tourists [6].
In summary, the Indonesian Minister of Tourism provides parameters for halal tourism as the provision of halal facilities and infrastructure which includes amenities, attraction, and accessibility [5].

\subsection{General practice of halal tourism}

Various countries have practiced halal tourism to attract tourists around the world, especially Muslims. From a study in Malaysia, it is stated that Islamic tourism can have a great influence on the Malaysian tourism industry from a social, environmental and political economic perspective [4].

"Islamic tourism can give high impacts on Malaysia's tourism industry from the perspectives of economic, social, environmental and political. This is because Islamic tourism provides new peculiar and universal needs which will influence to the development of tourism industry in Malaysia [4]."

In various applications of halal tourism in various regions of the world, Muslim tourists are the main target for tourists. This can be seen as various studies showing the application of halal tourism to increase Muslim tourist visits such as in the Andaman Gulf of Thailand [7] and the Malaysian tourism industry which is also developing halal tourism to attract Muslim visits in the world, even by establishing an Islamic Tourism center (ITC) by Ministry of Tourism. ITC defines Islamic tourism as "Sphere of Interest or activity that is related to travel to explore Islamic history, art, culture and Heritage and/or to experience the Islamic way of life, in conformity with the Islamic faith [4]." From this it can be seen that the main target in the practice of halal tourism should be aimed at Muslim tourists, without excluding non-Muslim tourists with the obligation to comply with halal norms in traveling.

\subsection{Halal tourism regulation and supervision of tourist dress ethics in Sabang city}

Tourist attitudes in decision making can be classified in five forms, namely need recognition, information seeking and information acquisition, evaluation of alternatives on choices and preferences, purchase or consumption decisions, and post-purchase behavior. This study categorizes tourist needs into three, namely hotels, restaurants and public areas [7].

In general, the focus of the development of halal tourism in various regions that is currently happening is the development of the application of halal from the tourism provider side, so that it is not offended by supervision on the tourist side. Tourist alludes are only focused on Muslim tourists, but not with non-Muslim tourists. So, this will cause problems when there are foreign tourists who travel to Islamic regions/cities whose people live in the norms and customs of Islamic law, especially in the ethics of dressing for non-Muslim tourists. Marine tourism destinations are tourist locations that are most in demand by foreign tourists who are non-Muslims, and become a "special" place for them to dress. Meanwhile, Islamic cities have strict norms and ethics in dressing in a closed manner. So that 
this opposite is the problem to focus on in terms of halal tourism.

Based on a study that the Aceh Ulama Consultative Assembly has carried out socialization in collaboration with the Aceh Islamic Shari'a Service, the Tourism Office, the wilayatul hisbah in order to implement, enforce and develop halal tourism. This party has also given a will for the government in the development of halal tourism such as in terms of dressing on the beach, where it is illegal to travel to the beach with minimal clothing [8].

The government has issued regulations governing Sabang city tourism as outlined in Sabang City Qanun number 9 of 2019 concerning the Sabang City Tourism Development Master Plan For 2019-2027, which is the latest qanun for the Sabang city tourism development plan. However, this qanun also does not explain in detail about the implementation of Halal tourism from various sides, both tourism providers and tourist visitors. So, this is what provides an opening for non-Muslim tourists to disobey halal norms, especially in dressing. Although this Qanun has alluded to in general the description of management based on halal values and local wisdom values as the identity of Sabang City Tourism. In article 10 point $\mathrm{a}$ it is stated that the tourism destination development policies include:

"Development of marine tourism products based on international standards of history and geology with management based on halal values and local wisdom values as the identity of Sabang City Tourism, and developing other community-based tourist attractions to strengthen the identity and competitiveness of tourism destinations [1]."

In the qanun mentioned above, Article 6 Letter $b$ states that the principles of regional tourism development include "Tourism development with ethical principles and principles of halal values (tourism development that implements, respects, and upholds socio-cultural norms and halal values, as well as applies the code of conduct of world tourism ethics [1]."

Article 15 paragraph 1 letters c and d states that the strategy in realizing the development of a tourism marketing system based on information technology includes:

"Setting the tourist market from Singapore, Malaysia, Thailand, and Australia as the main target market for foreign tourists, as well as the tourist market from the Middle East and the foreign tourist market with high interest in marine tourism activities and halal tourism as a potential target market for foreign tourists [1]."

And,

"Determining residents and tourists visiting all areas of Aceh Province, North Sumatra, DKI Jakarta, provinces on the islands of Sumatra and Java, as the main target market for domestic tourists in the city of Sabang, as well as the tourist market from marine tourism destinations and halal tourism in Indonesia as the target market. potential Indonesian tourists [1]."

The spirit of halal tourism development in the qanun above is only limited to the application by tourism managers as is done by halal tourism managers in the world. But in general, this is done because tourism managers focus and target Muslim tourists to visit these tourist sites. In relation to the city of Sabang as marine tourism, this city's tourism planning targets various countries in the world from various religious circles, because the mention is only on the classification of foreign tourists and domestic tourists. This is certainly very well done to be open to every tourist visit, provided that there are special regulations that clearly regulate norms and ethics in halal tourism visits that must be obeyed in detail, including in dressing well, and being socialized and supervised openly to every visitors.

The elaboration of the Ripparkot Qanun above, showed the spirit of realizing halal tourism has been proclaimed by firmly adhering to halal values and social norms. Certainly, this indicates that halal norms and values (a quality of tourism) are more important than promoting the number of visits to non-Muslim tourists who do not maintain social norms and halal values (a quantity of tourism). Basically, the quality and quantity of halal tourism can be realized at the same time by maximizing a complex and globally competitive development plan, by targeting visits by Muslim tourists and non-Muslim tourists who maintain the ethics and norms of halal attire.

\subsection{Opportunities for the development of kaffah halal tourism in the city of Sabang}

The tourism development of the city of Sabang must be committed to the vision and mission of its development. One of its visions as a sustainable maritime-based global halal tourism destination, is pursued with several missions, including as stated in the Ripparkot Qanun in article 8 letter a, namely

"Building an integrated sustainable world marine tourism destination, and based on halal values and local wisdom as the identity of Sabang City Tourism [1]."

In the article, it is stated about the values of local wisdom, which the City of Sabang is one of the cities in Aceh which also applies Islamic law and the local wisdom of its residents has been attached to an Islamic standard of living. In this case, the realization of halal tourism in the maritime-based city of Sabang does not only hold halal values but also local wisdom values, which means that in this case there are two values that must be maintained in the mission of halal tourism development in Sabang City.

The political strategy for the development of the city of Sabang is carried out with a mixed approach between top-down and bottom-up. This development policy was initiated by the formulation by the upper class, namely the central government through the Ministry of Tourism of the Republic of Indonesia to formulate policies regarding halal tourism which were then passed down to several provinces that have the potential to develop halal tourism in the regions, including Aceh. Furthermore, the halal tourism regulations were also handed down to the district/city government, in this case the City of Sabang. In the development of halal tourism, bottom-up actors are also involved, namely the tourism awareness group which is a community initiative group towards the importance of tourism awareness, and is fostered by the Tourism and Culture Office of Sabang City directly [8]. 
The development of Sabang city halal tourism by the above actors is carried out in accordance with the Sabang City Tourism Development Master Plan (Ripparkot) as stated in Qanun Number 9 of 2019, by also lowering complex rules on halal tourism. In article 2 points $\mathrm{d}$, $\mathrm{f}$, and $\mathrm{h}$, it is stated that Ripparkot (master plan for urban tourism development) aims to:

"Creating a tourism industry with international competitiveness and high credibility that is responsible for the natural, social and cultural environment through management that is based on halal values [1]".

And,

"Realizing the integration of tourism marketing with trade and investment, with provincial and national tourism marketing, as well as with maritime and halal tourism destinations in the world to build an image as a maritime-based world halal tourism destination [1]."

As well as,

"Realizing the integrated governance of Sabang City Tourism across sectors in the regions, between the central government and city governments, industry, society, academia, and the media in building halal tourism destinations that are internationally competitive and sustainable [1]".

Basically, the city of Sabang has a very big opportunity in the development of halal tourism because this city has been capitalized by the application of Islamic law in Aceh. However, the absence of special regulations regarding halal tourism causes the development to be not optimal.

There are several actors who play a role in the development of halal tourism, namely the Ministry of Tourism of the Republic of Indonesia, the Indonesian Ulema Council/Institute for Food, Medicine and Cosmetics, the Indonesian Ulema Council, the Aceh Culture and Tourism Office, the Aceh Ulema Consultative Assembly, the Halal Tourism Acceleration Team with the branding "The Light of Aceh", the mayor/deputy mayor of Sabang, the Tourism and Culture office of Sabang City, the Islamic law service/Satpol PP WH of Sabang City, the Sabang City People's Representative Council, the Sabang area concession agency, the Sabang City Ulemas Consultative Assembly, the Aceh traditional assembly, the association Indonesian HPI guides for the City of Sabang, the green community forum FKH Teurawah which is under the guidance of the Ministry of Public Works and Public Housing, pokdarwis/tourism awareness groups in the City of Sabang consisting of Gampung youth and funded by the APBG, travel agents, and lodging managers. In this case, the actors from the national, local to the individual and private levels of Sabang City as the driving force of development must synergize with each other and strive as much as possible in order to realize the direction and development goals to be achieved, namely Sabang City halal tourism [1]. According to the Fatwa of the Ulama Consultative Assembly of Aceh (MPU Aceh) number 7 of 2014 concerning tourism in Islam, that:

"Tourism is everything related to tourism, including the exploitation of tourist objects and attractions as well as businesses related to these fields. Tourism which contains elements of disobedience is haraam, and tourism which contains beneficial values is legally permissible. The Fatwa of the Aceh MPU has also called on the Aceh government to prioritize Islamic sharia values in tourism development in Aceh, socialize Sharia tourism to tourism managers and the community, prepare human resources for professional tour guides who understand sharia local wisdom, prioritize the promotion of Sharia tourism outside the region and country. Muslim countries prepare adequate worship facilities at tourist sites, place WH wilayatul hisbah personnel and other relevant officers at tourist sites, provide sanctions for tourism managers and tourists who violate Islamic sharia values. And the people of Aceh are also encouraged to participate in supervising tourism activities [9]."

The MPU fatwa above can be used as a guide for the government in implementing halal tourism in a kaffah manner and providing special derivatives for the Sabang city halal tourism regulations. This is because one of the challenges in the development of halal tourism in Sabang City is the absence of regulations/legal coverage that specifically regulate the concept of derivative halal tourism which includes tourism management and regulations for halal tourism visitors. The absence of detailed rules on halal tourism compliance for tourists will have an impact on tourists' non-compliance, including clothing. This can be seen clearly from the non-compliance of non-Muslim tourists in minimally dressed, which is still difficult to organize. So it is necessary to have supervision under a clear law to organize tourists to dress in halal tourist areas. By maximizing the application of halal identity in tourism through strengthening regulations and supervision, it will require every tourist including non-Muslims to comply with halal values and local wisdom. This can be seen as one of the great mosque tours in Malaysia, a form of respect by every religion by giving a cloth covering. The island of Sabang is likened to a valuable house for the Muslim community with a qanun (Islambased law) in it, so that tourists who visit still have to meet the elements of halal and local ethics.

In addition, maximizing the development of halal tourism in Sabang City must also be carried out through the construction of facilities that are globally competitive to attract more tourists. The provision of facilities and development that is internationally competitive is a very important step, by making Muslim tourists the main target and non-Muslim tourists who can accept the rules and norms of halal as the second target market. The level of visits to tourist areas by domestic and foreign tourists is very influential from modernity, facilities, convenience and beauty available.

Basically, this Qanun regarding Ripparkot Sabang is sufficient to regulate tourism in terms of development planning, management, and control. However, the application needs to be done more and more elite and modern tourism development to attract tourists in the world. On the other hand, in terms of managing the spirit of halal tourism, it is necessary to bring down special rules that regulate halal tourism in the city of Sabang to regulate all halal coffers that are kaffah. This is needed as a guide for tourists to visit, including socialization 
and supervision carried out on non-Muslim tourists who plan to have a maritime tour in Sabang City.

\section{Conclusion}

Marine tourism destinations are tourist locations that are most in demand by foreign tourists who are nonMuslims, and become a "special" place for them to dress. Meanwhile, Islamic cities have strict norms and ethics in dressing in a closed manner. So that this opposite is the problem to focus on in terms of halal tourism. The challenges in the development of halal tourism in Sabang City is the absence of regulations/legal coverage that specifically regulate the concept of derivative halal tourism which includes tourism management and regulations for halal tourism visitors.

The absence of detailed rules on halal tourism compliance for tourists will have an impact on tourists' non-compliance, including clothing. This can be seen clearly from the non-compliance of non-Muslim tourists in minimally dressed, which is still difficult to organize. So, it is necessary to have supervision under a clear law to organize tourists to dress in halal tourist areas. By maximizing the application of halal identity in tourism through strengthening regulations and supervision, it will require every tourist including non-Muslims to comply with halal values and local wisdom.

Dissemination of information and travel rules to tourists who arrive must also be massive by involving government officials, village officials, and also the community. The halal identity that remains inherent in every aspect of tourism control can even give a different prestige in the eyes of foreign tourists. Therefore, the government needs to consider the derivatives of these regulations in order to create universality in regulations and supervision of travel to foreign tourists.

Acknowledgment: Sincere thanks are due to the Research Center for Marince Sciences and Fisheries, Universitas Syiah Kuala for their effort in organizing the $10^{\text {th }}$ ICMR in conjunction with the $2^{\text {nd }}$ INSAEF. This research is funded by the Ministry of Education, Culture, Research, and Technology through Universitas Syiah Kuala, under the Research Institutions and Community Service with contract number: 174/UN11/SPK/PNBP/2021. The writing of this manuscript is supported by the Matching Fund Kedaireka funded by the Ministry of Education, Culture, Research, and Technology Indonesia awarded to the Research Center for Marine Sciences and Fisheries, Universitas Syiah Kuala.

\section{References}

1. P. K. Sabang, Rencana Induk Pembangunan Kepariwisataan Kota Sabang Tahun 2019-2027 (2019), p. Qanun of Sabang City No. 9

2. S. Khan, J. Hosp. Tour. Syst. 7, (2014)

3. T. Duman, in World Islam. Tour. Forum (2011), p. 720
4. L. M. Kamarudin and H. Nizam, in Proc. Int. Conf. Tour. Dev. (2013), p. 403

5. R. Hakim and Muslikhati, J. Ilm. Ekon. Islam 5, 170 (2019)

6. K. Pariwisata, Panduan Penyelenggaraan Pariwisata Halal (2019)

7. P. Sripraset, O. Chainin, and A. Rahman, Underst. Behav. Needs Halal Tour. Andaman Gulf Thail. a Case Asian Muslim 2, 218 (2014)

8. M. Ulfa, H. Kusmanto, and Warijo, J. Adm. Publik 9, 78 (2019)

9. M. P. U. (MPU) Aceh, Fatwa of Islamic View on Tourism (2014), p. Number 7 